\title{
REVIEW
}

\section{Toxicological aspects of depleted uranium}

\author{
Jiří Patočka ${ }^{1,2}$, Jiří Kassa $^{1}$, Rudolf Štětina ${ }^{1}$, Gustav Šafr ${ }^{3}$, Josef Havel ${ }^{4}$ \\ ${ }^{1}$ Department of Toxicology, Military Medical Academy, Hradec Králové, Czech Republic \\ ${ }^{2}$ Department of Radiology, The University of South Bohemia, Česke Budějovice, Czech Republic \\ ${ }^{3}$ Department of Combat and Transport Vehicles, Faculty of Military Technology, Brno Military \\ Academy, Brno, Czech Republic \\ ${ }^{4}$ Department of Analytical Chemistry, Faculty of Science, Masaryk University, Brno, Czech Republic
}

Received $16^{\text {th }}$ May 2003.

Revised $17^{\text {th }}$ October 2003.

Published online $20^{\text {th }}$ October 2003.

\begin{abstract}
Summary
Depleted uranium is a byproduct of the uranium enrichment process and has been used for decades in different applications. Recently depleted uranium is used as an anti-armour munition because of its profitable physical properties. One of these, the ability to ignite and burn at very high temperatures, may result in the formation of an aerosol of very small uranium oxide clusters, which may be inhaled. It is alleged that these particles represent a new battlefield hazard because of the radioactivity and chemical toxicity of uranium.
\end{abstract}

Keywords: absinthe - thujone - composition - metabolites - detoxification

\section{INTRODUCTION}

Depleted uranium (DU) is a byproduct of the uranium enrichment process and has been used for decades in medical and industrial applications, radiation shielding, counterbalance weights in aircraft and ships, and more recently, in military armour and ammunition.

It was used in the development of major weapon systems because of its high density and superior mechanical properties. In addition, it is relatively wide-spread and cheap. Recently it has substituted for lead in bullets and missiles. DU is used in kinetic energy weapons consisting of a penetrator rod of DU which, when fired at high velocity, can penetrate the heavy armour of modern battle tanks. DU in weapons, used for military purposes, can change into various compounds by burning when the projectiles hit a target. It can enter tanks and armoured cars as an aerosol of uranium. Because DU is low level radioactive and a toxic heavy metal, it is potentially dangerous as an environment pollutant for military personnel as well as civilians. It is relatively toxic to humans, both chemically as a heavy metal and radiologically as an alpha particle emitter, which is dangerous in cases of internal contamination (Patočka et al. 2000). The possibility of exposure to DU represents a new battlefield hazard (Murray et al. 2002).

\section{CHEMICAL AND PHYSICAL PROPERTIES OF DU}

DU strongly differs from natural uranium since it has been separated chemically and physically from all other elements, especially from the daughters of the various decay chains. DU contains about $99.7 \%$ $\mathrm{U} 238$ and less than $0.3 \%$ U 235 while natural uranium contains $99.3 \%$ U 238 and $0.7 \%$ U 235. In addition, it is alloyed with $1.75 \% \mathrm{Nb}$. Uranium alone is a very heavy metal with a melting point of 
$1130{ }^{\circ} \mathrm{C}$, and it decays with a mean half- life of 6.510 years, yielding a decay rate of $12.2 \mathrm{~Bq} / \mathrm{g}$. DU is only hazardous in case of inhalation or ingestion exposure. Its radioactivity is less than $50 \%$ of the radioactivity in natural uranium.

Uranium as a metal is autopyrophoric and can burn spontaneously at room temperature in the presence of air, oxygen and water. At temperatures of $200-400{ }^{\circ} \mathrm{C}$, uranium powder is able to selfignite in atmospheres of carbon dioxide and nitrogen. Oxidation of uranium under certain conditions may generate sufficient energy to cause an explosion (Gindler 1973). Friction caused by the penetration of bullets or missiles into a tank or armoured vehicle can cause the ignition of uranium, forming a concentrated ceramic aerosol composed of insoluble particles of uranium oxide, $\mathrm{UO}_{2}$ or $\mathrm{UO}_{3}$, in a mist or a fog, capable of killing most personnel in the vehicle. Insoluble uranium oxide particles when they are inhaled and scavenged to the lymph nodes, represents dangerous material (Priest 2001). In addition, on explosion DU generates a great many very chemically reactive uranium oxide clusters, which can retain hitherto unrecognized biological effects.

The formation of superfine uranium oxide clusters has been described for example, during Fast Atom Bombardment (FAB) of uranium(VI) salts in organic matrices which produces clusters of general formula $\left(\mathrm{UO}_{2}\right)_{x} \mathrm{O}_{y}^{+}$with $x$ up to 40 where for each value of $x$ there is a series of values $y$. The $\mathrm{O}: \mathrm{U}$ ratio depends not only on the size of the cluster $(x)$ but also if $x$ is even or odd. However, as $x$ tends to 40 all cluster series tend to a final stoichiometry of $\mathrm{O}: \mathrm{U}=2.5: 1$ (Kemp et al. 1995).

In addition, it was observed recently in a Matrix Assisted Laser Desorption Ionisation Time of Flight Mass Spectrometry (MALDI TOF MS) analysis of uranium (Havel et al. 1999), (sensitive uranium determination with a detection limit down to $10^{-12}$ Mole is possible) that the formation of another type of cluster takes place during intensive laser beam shot.The structure of clusters has been resolved and details published recently (Soto-Guerrero et al. 2001). In this case, a different series of the uranium clusters than those with FAB were observed. Three different families of formula $\left(\mathrm{UO}_{2}\right)_{x} \mathrm{O}_{y}{ }^{+}$, and two of formula $\left(\mathrm{UO}_{2}\right)_{x} \mathrm{O}_{y}{ }^{2+}$ were found. For these five groups, as $x$ increases, the $\mathrm{O}: \mathrm{U}$ ratio tends to 3 . The relationship between neighboring clusters can be described as

$$
\left(\mathrm{UO}_{2}\right)_{x} \mathrm{O}_{y}^{+} \leftrightarrow\left(\mathrm{UO}_{2}\right)_{x-1} \mathrm{O}_{y-1}{ }^{+}+\mathrm{UO}_{3} .
$$

An example of mass spectra showing the evidence of the clusters uranium oxide clusters formation is given in Fig. 1.

An example of the scheme of the compounds formed is given below for one of the series:

$$
\begin{aligned}
& \mathrm{UO}_{2}^{+}\left(+\mathrm{UO}_{3}\right) \rightarrow \mathrm{U}_{2} \mathrm{O}_{5}^{+}\left(+\mathrm{UO}_{3}\right) \rightarrow \mathrm{U}_{3} \mathrm{O}_{8}{ }^{+} \\
& \left(+\mathrm{UO}_{3}\right) \rightarrow \mathrm{U}_{4} \mathrm{O}_{11}{ }^{+}\left(+\mathrm{UO}_{3}\right) \rightarrow \mathrm{U}_{5} \mathrm{O}_{14}{ }^{+}\left(+\mathrm{UO}_{3}\right) \\
& \rightarrow \mathrm{U}_{6} \mathrm{O}_{17}{ }^{+}\left(+\mathrm{UO}_{3}\right) \rightarrow \mathrm{U}_{7} \mathrm{O}_{20}{ }^{+}\left(+\mathrm{UO}_{3}\right) \rightarrow \mathrm{U}_{8} \mathrm{O}_{23}{ }^{+} \\
& \left(+\mathrm{UO}_{3}\right) \rightarrow \mathrm{U}_{9} \mathrm{O}_{26}{ }^{+}\left(+\mathrm{UO}_{3}\right) \rightarrow \mathrm{U}_{10} \mathrm{O}_{29}{ }^{+}\left(+\mathrm{UO}_{3}\right) \rightarrow \\
& \mathrm{U}_{11} \mathrm{O}_{32}{ }^{+}\left(+\mathrm{UO}_{3}\right) \rightarrow \mathrm{U}_{12} \mathrm{O}_{35}{ }^{+} \ldots
\end{aligned}
$$

The clusters are formed starting from $\mathrm{UO}_{3}{ }^{+}$, $\mathrm{UO}_{2}^{+}$or $\mathrm{UO}^{+}$ions formed by laser ablation aggregating step by step with $\mathrm{UO}_{3}$ oxide.

We would like to express our strong opinion that conditions at DU penetrator impact with the target are very similar to those of high energy laser shot impact to uranium compounds and that such super-fine particles are formed because similar temperatures are reached as well as light emission and the pyrophoric properties of metallic uranium. Such superfine uranium oxide clusters could represent a hazard to soldiers and the environment, and attention should be paid to this in the light of the hundreds of tons of DU already dispersed in former battlefields or with respect to the increased military use of DU.

\section{CHEMICAL AND RADIOLOGICAL HAZARDS OF DU}

Uranium presents both chemical and radiological hazards, but there are some problems with the comparison of these hazards (Ebinger and Hansen 1994). Different reports on the health hazard of DU munitions have concluded that this metal used on the battlefield probably does not lead to any measurable excess of cancers. The explosion of uranium missile can kill everyone in the target tank, but radioactive aerosol of uranium is able to disperse in the air, tens of kilometers from the point of release. It can be also be stirred up in dust and re-suspended in the air with wind or human movement. Following inhalation exposure, very small uranium particles can stay in the human body for years, irradiating the tissue with powerful alpha particles within about a 30 micron sphere, causing damage to cells.

Uranium can also be ingested and damage the gastrointestinal tract. In addition, it penetrates through lung tissue to the blood stream and can be stored in liver, kidney, bone or other tissues for years, irradiating all tissues located near its storage place. It has also an influence on the blood cells that are the important part of the immune system, and can damage the renal system in the case of urine elimination. It can also initiate cancer or promote cancers which have been initiated by other carcinogens. This radiological toxicity is combined with the chemical toxicity of uranium, comparable with the toxicity of other heavy metals, for example with lead, or nickel. 


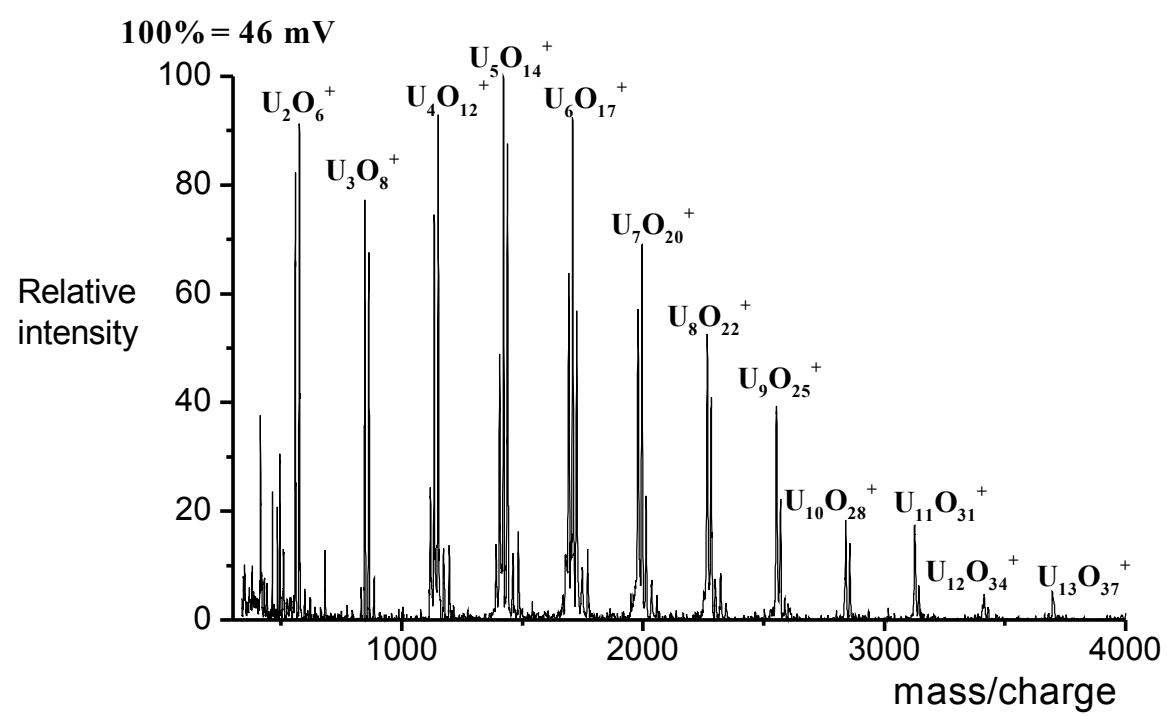

Fig. 1. An example of mass spectra of uranium observed in Laser Desorption Ionisation (LDI). The clusters are formed starting from $\mathrm{UO}_{3}{ }^{+}, \mathrm{UO}_{2}{ }^{+}$or $\mathrm{UO}^{+}$ions formed by laser ablation aggregating step by step with $\mathrm{UO}_{3}$ oxide

\section{TOXICOKINETICS AND TOXICODYNAMICS OF DU}

The soluble compounds of uranium, such as uranium hexafluoride, uranyl fluoride, uranium tetrachloride, and uranyl nitrate hexahydrate, can penetrate to the blood from the alveolar pockets in the lungs within days of exposure. Although inhalation products are also transported through coughing and mucocilliary action to the gastrointestinal tract, only about 2 per cent of this fraction is actually absorbed into the body fluids through the intestines. Therefore, all of the research papers on the acute effects of uranium describe the inhalation exposure to these soluble uranium compounds. The main acute effect of inhalation of soluble uranium compounds is damage to the renal system. The bone seems to be the main long term storage place of these compounds in the human body.

Particles of uranium smaller than 2.5 microns are usually deposited in the lungs and pulmonary lymph nodes where they can remain for years. According to research done in the UK by the NRPB, ceramic uranium is formed when uranium ignites through friction, as happened in the Gulf War. In this form, uranium usually penetrates the lungs to the blood twice more slowly than non-ceramic uranium.A very small portion of inhaled uranium $(2 \%)$ can be transported to the gastro-intestinal tract, where is absorbed through the intestines. This fraction of the inhaled compound can damage the gastro-intestinal (GI) tract as it passes through because it emits damaging alpha particles with statistical regularity. The residence time of the insoluble uranium compounds in the GI tract is estimated in years.
The chemical action of all isotopic mixtures of uranium (depleted, natural and enriched) is identical. Current evidence from animal studies suggests that the chemical toxicity is largely due to its chemical effect on kidney tubular cells, leading to nephritis. The differences in toxicity based on the solubility of the uranium compound are more striking: water soluble salts are primarily renal and systemic chemical toxicants; insoluble chemical compounds are primarily lung chemical toxicants and systemic radiological hazards. Immediately following uranium dioxide entering the blood, hexavalent uranium is formed, which is also a systemic chemical toxicant. The slow excretion rate of the uranium oxide is favorable for kidney and tubule repair and regeneration. Moreover, much uranium is still being stored in the body and has not yet passed through the kidneys because of the long biological half-life. The direct damage to lungs and kidneys by uranium compounds is thought to be the result of their combined radiation and chemical properties. It is difficult to assign a portion of the damage to these separate factors because they cannot be separated in life (Stradling et al. 1988).

Animal and human research indicate that inhalation of insoluble uranium dioxide is associated with general damage to pulmonary tissue, usually non-cancerous damage to alveo- lar epithelium. This pulmonary damage can lead to emphysema or pulmonary fibrosis (Cooper et al. 1982, Dungworth 1989, Saccamanno et al. 1989, Stokinger 1981, Wedeen 1992). Animal studies demonstrate that uranium compounds cause adverse hematological disturbances (Dygert 1949, Spiegel 1949, Stokinger et al. 1953, Cross et al. 1981). 


\section{GENOTOXICITY OF DU}

During the Persian Gulf War several US military personnel were wounded by shrapnel fragments containing DU. Analyses indicated a significant increase in urine uranium levels above natural background levels. An examination of the potential mutagenicity of DU internalization is necessary for the understanding of the etiology of potential disease development. Miller et al. (1998a) followed the mutagenicity of urine of rats, to which DU pellets, were implanted subcutaneously. The authors found a dose- and time- dependent increase of urine mutagenicity, tested by Ames Salmonella typhimurium test by strains TA 98 and mixed strains TA-7001-7006. DU internalization presents a unique toxicological problem, because it combines chemical toxicity with radiological exposure.

DU-uranyl chloride has the capacity to transform human osteoblastoma (HOS) cells (Miller et al. 1998b). The transformation frequency was slightly higher in comparison to the transformation frequency induced with nickel sulfate. Results showed that the mechanism of the carcinogenic effect of DU might be comparable to other heavy metal compounds (e.g., nickel). This mechanism might be connected with an inhibition of DNA repair in heavy - metal treated cells. This hypothesis seems to be supported by findings ( $\mathrm{Au}$ et al. 1995, 1998) of a decreased DNA repair capacity in individuals residing near uranium mining/milling facilities.

\section{MEDICINAL EXPERIENCES WITH HUMAN EXPOSURE TO DU}

During the Gulf War, munitions and armoured vehicles containing DU were used for military purposes for first time. Iraq and northern Kuwait were a virtual testing range for depleted-uranium weapons. Over 940,000 30-millimeter uranium tipped bullets and more than 14,000 large caliber DU rounds were disposed during Operation Desert Storm/Desert Shield. (U.S. Army Environmental Policy Institute). Between 300 and 800 tons of DU particles and dust have been scattered over the ground and the water in Kuwait, Saudi Arabia and Iraq. As a result, hundreds of thousands of people, both civilians and soldiers, have suffered from the effects of exposure to these radioactive weapons.

In October 1998, the WHO undertook a two year study of the increasing cancer rates, especially leukemia, in young children, which have been noted in southern Iraq where the war actions took place. The WHO report is not out yet, but recent data from Iraq tell the story of even more dramatic increases in cancer rates, especially among the Iraqi veterans who participated in the war. In the West, thousands of veterans are recognized to be seriously ill with an unknown syndrome, detected in their urine as late as 7 or 8 years after the war. Moreover, DU has been used by the US and Britain not only against Iraq but also in Bosnia and in Kosovo. The Human Rights Commission has requested that the Secretary General prepare a written report on DU and certain other weapons of mass destruction (Resolution 1997/36). Not only are war victims suffering from the various forms of damage, but also genetic damage can be passed on to their offspring.

\section{TOLERABLE DAILY INTAKE (TDU) OF URANIUM}

TDU of uranium is dependent on the route of administration because pharmacotoxic parameters are different in the case of inhalation or ingestion.

\section{TDU for Inhalation}

The study ATSDR (1997) reviews all published data on animal studies dealing with URAnium toxicity. A study performed by Stokinger (1953)on dogs is used in referring to the hazard from chronic inhalation of soluble forms of uranium: it showed that uranium concentrations of $0.15 \mathrm{mg}$ $\mathrm{U} / \mathrm{m}^{3}$ in air produced no observable adverse effect. From this figure, a "minimal risk" inhalation level for humans of $1 \mu \mathrm{g} / \mathrm{m}^{3}$ is derived, applying a number of safety factors. In another review (Jacob et al. 1997), performed for the German Federal Environmental Agency, another study by Stokinger (1953) on rats has been used: The rat study showed slight impacts to the kidneys at uranium resorption rates of $2.6 \mu \mathrm{g}$ per $\mathrm{kg}$ per day. This rate corresponds to uranium concentrations of $40 \mu \mathrm{g}$ per $\mathrm{m}^{3}$ in air. Applying a number of safety and conversion factors, the authors obtain a "tolerable" level of $0.07 \mu \mathrm{g} / \mathrm{m}^{3}$ uranium in air; this is 14 times lower than the above mentioned ATSDR level.

\section{TDU for Ingestion}

The "minimal risk" level for intermediate-duration ingestion proposed by ATSDR (1997) is an oral uptake of $1 \mu \mathrm{g}$ of uranium per $\mathrm{kg}$ body weight per day. This is based on adverse effects observed by 
Ortega et al. (1989) in rats at uptakes of $1.1 \mathrm{mg}$ per $\mathrm{kg}$ per day. Jacob et al. (1997) proposes a "tolerable" uptake of $0.7 \mu \mathrm{g}$ per kg body weight per day. This value is based on adverse effects observed by McDonald-Taylor et al. (1992) in kidneys of rabbits at resorption rates of $3.2 \mu \mathrm{g} \mathrm{U}$ per $\mathrm{kg}$ body weight per day The WHO has established a TDI for uranium of $0.6 \mu \mathrm{g} / \mathrm{kg}$ body weight per day (WHO 1998). This is based on adverse effects observed by Gilman et al. (1998) in kidneys of rats at uptakes of $60 \mu \mathrm{g} \mathrm{U}$ per kg body weight per day.

\section{CONCLUSIONS}

The use of depleted uranium on the battlefield can result in its intake in various ways. Of particular concern is that when a DU penetrator hits a hard target, such as armour plate, it can produce a dense cloud of fine dust containing very small particles of different uranium oxide clusters. This dust can be inhaled by personnel in the vicinity and later by people working on struck vehicles or casualties contaminated with the uranium oxide dust. Radioactivity and toxicity of uranium foreshadow a possible risk to the environment and human health, but for a more precise survey of the real risk further research is needed.

\section{REFERENCES}

ATSDR: U.S. Agency for Toxic Substances and Disease Registry (ATSDR): Toxicological Profile for Uranium, Draft for Public Comment, September 1997, p. 350.

Au W.W., M.A. McConnel, G.S. Wilkinson, V.M. Ramanujam, N. Alcock: Population monitoring experience with residents exposed to uranium mining/milling waste. Mutation Res. 405: 237-245, 1998.

Au W.W., R.G. Lane, M.S. Legator, E.B. Whorton, G.S. Wilkinson, G.J. Gabehart: Biomarker monitoring of a population residing near uranium mining activities. Environ. Health Perspect. 103: 466-470, 1995.

Cooper J.R., G.N. Stradling, H. Smith, S.E. Ham: The behavior of uranium 233 oxide and uranyl 233 nitrate in rats. Int. J. Rad. Biol. 41: 421-433, 1982.

Cross F.T., R.F. Palmer, R.H Busch, R.E. Filipy, B.O. Stuart: Development of lesions in Syrian golden hamsters following exposure to radon daughters and uranium dust. Health Physics 41: 1135-1153, 1981.
Dygert H.P.: Pharmacology and Toxicology of Uranium Compounds. McGraw Hill Books Inc. 1949, pages 647-652, 666-672, and 673-675.

Ebinger M.H. and W.R Hansen: Depleted Uranium Human Health Risk Assessment, Jefferson Proving Ground, Indiana. LA-UR-94-1809, 1994.

Gilman A.P, D.C. Villeneuve, V.E Secour, A.P. Yagminas, B.L. Tracy, J.M. Quinn, V.E. Valli, R.J. Willes, M.A. Moss: Uranyl nitrate: 28-day and 91-day toxicity studies in the Sprague-Dawley rat. Toxicol. Sci. 41: 117-128, 1998.

Gindler J.E.: Physical and Chemical Properties of Uranium. In: Uranium, Plutonium and Transplutonic Elements. Editors: Hodge et al. New York NY: Springer Verlag 1973, pp. 69164.

Havel J., D.Gajdošová, J. Soto-Guerrero: Matrixassisted laser desorption-ionisation time- of-flight mass spectrometry as a tool for speciation analysis?, in: Evaluation of Speciation Technology, Workshop Proceedings, Tokai-Mura, Japan, 26-28 October 1999, organized by AEN/NEA.

Jacob P., G. Pröhl, K. Schneider, J.-U. Voß: Machbarkeitsstudie zur Verknüpfung der Bewertung radiologischer und chemisch-toxischer Wirkungen von Altlasten, Umweltbundesamt, Texte 43/97, Berlin 1997, p. 145 .

Kemp T.J., K.R. Jennings., P.A. Resd: Formation and decomposition of uranium.oxygen clusters in fast-atom-bombardment of dioxouranum(VI) salts. J. Chem. Soc. Dalton 5: 885-889, 1995.

McDonald-Taylor C.K., M.K Bhatnagar, A. Gilman, A. Yamingas, A. Singh: Uranyl nitrate induced glomerular basement membrane Alterations in rabbits: A quantitative analysis. Bull. Environ. Conta.Toxicol. 48: 367-373, 1992.

Miller A.C., A.F. Fuciarelli, W.E. Jackson, E.J. Ejnik, C. Emond, S. Strocko: Urinary and serum mutagenicity studies with rats implanted with depleted uranium or tantalum pellets. Mutagenesis 13: 643-648. 1998b.

Miller A.C., W.F. Blakely, V. Livengood, T. Whittaker, J. Xu , J.W. Ejnik, M.M. Hamilton, E. Parlette, T.S. John, H.M. Gerstenberg, H. Hsu: Transformation of human osteoblast cells to tumorigenic phenotype by depleted uraniumuranyl chloride. Environ. Health. Perspec.106: 465-471, 1998a.

Murray V.S.G., M.R. Bailey, B.G. Spratt: Depleted uranium: a new battlefield hazard. Lancet 360: 31-32, 2002.

Ortega A., J.L. Domingo, J.M. Llobet, J.M. Thomas, J.L. Paternain: Evaluation of the oral toxicity of uranium in a 4-week drinking 
water study in rats. Bull. Environ. Cont.Toxicol. 42: 935-941, 1989.

Patočka J., J. Kassa, R. Štětina: Toxikologie uranu. Voj. Zdrav. Listy 69: 199-205, 2000.

Priest N.D.: Toxicity of depleted uranium. Lancet 357: 244-246, 2001.

Soto-Guerrero J., D. Gajdošová, J. Havel: Uranium oxide clusters by laser desorption ionisation during MALDI-TOF MS analysis of uranium(VI), J. Radioanal. Nucl. Chem. 249: 139-143, 2000.

Spiegel C.J.: Pharmacology and Toxicology of Uranium Compounds. McGraw Hill Books Co. Inc. 1949.

Stokinger H.E.: Uranium. In Clayton C.D. and F.E. Clayton (eds): Industrial Hygiene and Toxicology. Vol 2A, $3^{\text {rd }}$ Edition. John Wiley and Sons, New York 1981, pp. 1995-2013..

Stokinger H.E., R.C.Baxter, H.P Dygert: Toxicity Following Inhalation for 1 and 2 Years. In Voegtlin C. and C. Hodge (eds): Pharmacology and Toxicology of Uranium Compounds I-IV, New York 1953.

Stradling G.N., J.W. Stather, S.A. Gray, J.C. Moody, A. Hodgson, D. Sedgwick, N. Cooke: The metabolism of ceramic uranium and non-ceramic uranium dioxide after deposition in the rat lung. Hum. Toxicol. 7: 133-139, 1988.

Thun M.J., D.B. Baker, K. Steenland, A.B. Smith, W. Halperin, T. Berl: Renal toxicity in uranium mill workers. Scand. J. Work Environ. Health. 11: 83-90, 1985.

Wedeen R.P.: Renal diseases of occupational origin. Occup. Med. 7: 449-463, 1992.

WHO: World Health Organization: Guidelines for Drinking-water Quality, Second Edition, Addendum to Volume 2: Health Criteria and Other Supporting Information, WHO/EOS/98.1, Geneva 1998, 283 p.

\section{Address:}

Jiří Patočka, Department of Toxicology, Military Medical Academy, Šimkova 878, 50001 Hradec Králové, Czech Republic; patocka@pmfhk.cz 